\title{
Effect of Botanical Fertilizer on Herb Yield and Quality of Basil (Ocimum canum L.)
}

\author{
Swati Barche $^{1}$ and Kamal S. Kirad ${ }^{2 *}$ \\ ${ }^{1}$ R.V.S.K.V.V, Department of Horticulture, College of Agriculture, \\ Indore (M.P.) 452001, India \\ ${ }^{2}$ R.V.S.K.V.V, KVK, Dhar (M.P.), India \\ *Corresponding author
}

\begin{abstract}
A B S T R A C T
Basil (Ocimum canum) is cultivated primarily for the essential oil which is used by cosmetics, confectionary and pharmaceutical industries. The modern day intensive crop cultivation requires extensive use of chemical fertilizers but fertilizers are not only in short supply but they are expensive in developing countries. Therefore the current trend is to explore the possibility of supplementing chemical fertilizers with organic ones, more particularly bio and botanical fertilizers. Biovita is a unique botanical fertilizer extracted from freshly harvested sea-weed Ascophyllum nodosum, nornagian weed. There is a strong need to boost the productivity of this crop. The higher productivity of tulsi can appreciably be achieved through adoption of improved cultural practices. The field experiment was undertaken on var. OC-11 at AICRP, MAP and Betelvine, JNKVV, Jabalpur during 20112012 in Randomized Block Design with four replications. Total nine treatments comprising of soil application @ $20 \mathrm{~kg} / \mathrm{ha}$, foliar spray $500 \mathrm{ml}, 625,725 \mathrm{ml} \mathrm{ha}^{-1}$ at 25,45 and 65 days after transplanting, respectively. Both Soil+ foliar sprays also tried. The highest plant height, leaf size, stem length, maximum herb yield, highest oil content, highest linalool (\%), methyl chavicol (\%) and highest gross return was found in biovita @ $20 \mathrm{~kg} / \mathrm{ha}+500 \mathrm{ml}+625 \mathrm{ml} / \mathrm{ha}$ and minimum values were associated with control.
\end{abstract}

\section{Introduction}

Basil (Ocimum canum L.) belongs to family labiates. Economically important part of the plant is mainly of its leaves and tender parts of shoots which yield essential oils. The essential oils of basil contains heterogeneous group of aromatic compounds having immense value as flavor as well as fragrance and also in medicines. An ideal fertile soil is not only characterized by optimum physical properties and chemical constituents conducive for plant growth but also by microbiological processes, which are maintained in equilibrium. In fact, wild ecosystem have sustained through centuries by means of such natural inter conversions of essential elements. The modern day intensive crop cultivation requires extensive use of chemical fertilizers but fertilizers are not only in short supply but they are expensive in developing countries. Therefore the current trend is to explore the 
possibility of supplementing chemical fertilizers with organic ones, more particularly bio and botanical fertilizers. Biovita is a unique botanical fertilizer extracted from freshly harvested sea-weed Ascophyllum nodosum, nornagian weed. It is a store house of over 60 naturally occurring major and minor nutrients, amino acid and trace minerals. Judicious use of biovita supplements a well-balanced crop nutrition program. Increased productivity is a result of proper utilization of the nutrients provided. It also enhances resistance of the plants to environmental and moisture stress conditions. There is a strong need to boost the productivity and ensure the better quality of this crop. The higher productivity of tulsi can appreciably be achieved through adoption of improved cultural practices.

\section{Materials and Methods}

A field trial conducted on var. OC-11 at AICRP, MAP and Betelvine, JNKVV, Jabalpur during 2011-2012 in Randomized Block Design with four replications. The treatments being foliar spray as well as soil application. Soil application with Biovita granules @ 20kg/ ha, and foliar spray with biovita liquid @500ml at 25DAT, 625ml at 45DAT and at $725 \mathrm{ml}$ at 65 DAT were tried. Total nine treatments comprising of soil application, foliar spray and both soil+ foliar spray. The data pertaining to growth, yield and quality parameters were calculated and analyzed by the standard procedures given by Panse and Sukhatme (1989).

\section{Results and Discussion}

The data presented in Table 1 revealed that the significant effect was observed on growth, yield and quality attributes. Maximum growth was recorded with Biovita @ 20kg/ha +500ml $+625 \mathrm{ml}$ as evidenced by plant height, leaf size, stem length, herb yield, whereas significantly poor growth was recorded with control. Significantly maximum average plant height $(39.48 \mathrm{~cm})$ was observed with soil application of Biovita @ 20kg/ha +foliar spray of Biovita@500ml and 625mlat 25 and 45 days after Transplanting, respectively as compared to control $(15.33 \mathrm{~cm})$. Similarly, leaf size $(8.28 \mathrm{~cm})$, stem length $(18.43 \mathrm{~cm})$ and herb yield $(36.22 \mathrm{q} / \mathrm{ha})$ also recorded maximum under the same treatment, while minimum values for these characters $(4.43 \mathrm{~cm}, 11.27 \mathrm{~cm}$, and $21.22 \mathrm{q} /$ ha respectively) were found with control. The results are in the agreement with the findings of the Thakar et al., (1987) with the application of Azolla @ 1-5\%.and Alkaffa and Hassan (2007) also found same results. Increased in growth and yield might be due to the nature of Biovita as growth promoter and having macro and micro elements. Higher growth may be take place by two mechanism first by promoting the transport of $\mathrm{H}+$ ions across the cell walls and increasing their extensibility and second by inducing the transcription of specific mRNA'S necessary for sustained growth.

Regarding the quality traits, all the doses of Biovita had a significant effect on oil content $(\%)$, Linalool (\%) in oil, Methylchavicol (\%) in oil. Significantly average oil content $0.71 \%$, Linalool $11.40 \%$ and methyl chavicol $82.39 \%$ were recorded with biovita@20 kg/ha+ 500 $\mathrm{ml}+625 \mathrm{ml} / \mathrm{ha}$ followed by foliar spray of biovita@ $500 \mathrm{ml}+625 \mathrm{ml}+750 \mathrm{ml}$ at 25, 45 and 60DAT, respectively. Minimum values viz. $0.55 \%, \quad 7.99 \%$ and $82.20 \%$ were associated with control. Biovita is a store house of over 60 naturally occurring major and minor nutrients, amino acid and trace minerals such as Boron, Molybdenum, Copper, Iron, Zinc, Manganese, silicon, Cobalt, Aluminium, Calcium, Magnesium, Potassium and plant development substances comprising of Enzymes, Protein, Cytokinin, Amino Acids, Vitamins, Gibberellins, Auxins etc., which enhance the plant development, colour and vigour. 
Table.1 Response of the treatments on different traits of basil

\begin{tabular}{|c|c|c|c|c|c|}
\hline Treatments & $\begin{array}{l}\text { Plant } \\
\text { height } \\
(\mathrm{cm})\end{array}$ & $\begin{array}{c}\text { Leaf } \\
\operatorname{size}(\mathrm{cm})\end{array}$ & $\begin{array}{c}\text { Stem } \\
\text { length }(\mathrm{cm})\end{array}$ & $\begin{array}{c}\text { Herb } \\
\text { yield(q/ha) }\end{array}$ & $\begin{array}{c}\text { Oil } \\
\text { content } \\
(\%)\end{array}$ \\
\hline $\begin{array}{c}\text { To-Control (no application of } \\
\text { Biovita) }\end{array}$ & 15.33 & 4.43 & 11.27 & 21.22 & 0.28 \\
\hline $\begin{array}{c}\text { T1-Biovita @ } 20 \mathrm{~kg} / \mathrm{ha} \text { soil } \\
\text { application at transplanting and } 45 \\
\text { DAT }\end{array}$ & 18.47 & 5.69 & 12.13 & 22.38 & 0.37 \\
\hline $\begin{array}{l}\text { T2- Biovita @ } 500 \mathrm{ml} \text { and } 625 \mathrm{ml} \\
\text { (25 and 45DAT, resp.) foliar spray }\end{array}$ & 20.66 & 5.87 & 13.10 & 25.61 & 0.41 \\
\hline $\begin{array}{l}\text { T3- Biovita @ } 500 \mathrm{ml} \text { and 750 } \mathrm{ml}(25 \\
\text { and 45DAT, resp.) }\end{array}$ & 25.36 & 5.98 & 12.97 & 28.32 & 0.42 \\
\hline $\begin{array}{c}\text { T4-Biovita @ } 500 \mathrm{ml}, 625 \mathrm{ml} \text { and } \\
\text { 750ml, (25, } 45 \text { and } 60 \text { DAT, resp.) } \\
\text { Foliar spray }\end{array}$ & 33.40 & 7.61 & 17.77 & 35.90 & $\overline{0.55}$ \\
\hline $\begin{array}{l}\text { T5-Biovita @ } 20 \text { kg/ha + } 750 \text { ml } \\
\text { spray (25 DAT) soil + foliar spray }\end{array}$ & 29.14 & 6.14 & 14.13 & 29.68 & 0.45 \\
\hline $\begin{array}{l}\text { T6- Biovita @ } 20 \text { kg/ha + } 625 \mathrm{ml} \\
\text { spray ((25 DAT) soil + foliar spray }\end{array}$ & 27.16 & 6.53 & 14.98 & 33.18 & 0.48 \\
\hline $\begin{array}{l}\text { T7- Biovita @ 20kg/ha }+500 \mathrm{ml} \text { and } \\
625 \mathrm{ml}\end{array}$ & 39.48 & 8.28 & 18.43 & 36.22 & 0.71 \\
\hline $\begin{array}{l}\text { T8-Biovita @ } 20 \mathrm{~kg} / \mathrm{ha}+500 \mathrm{ml}, 625 \\
\mathrm{ml} \text { and } 750 \mathrm{ml} \text {, (Transplanting time, } \\
\qquad 25,45 \text { and } 60 \mathrm{DAT} \text {, resp.) }\end{array}$ & 32.15 & 7.15 & 15.10 & 31.63 & 0.52 \\
\hline SEm \pm & 2.45 & 0.13 & 1.16 & 1.22 & 0.09 \\
\hline C.D. at $5 \%$ & 4.92 & 0.37 & 3.306 & 4.07 & 0.102 \\
\hline
\end{tabular}




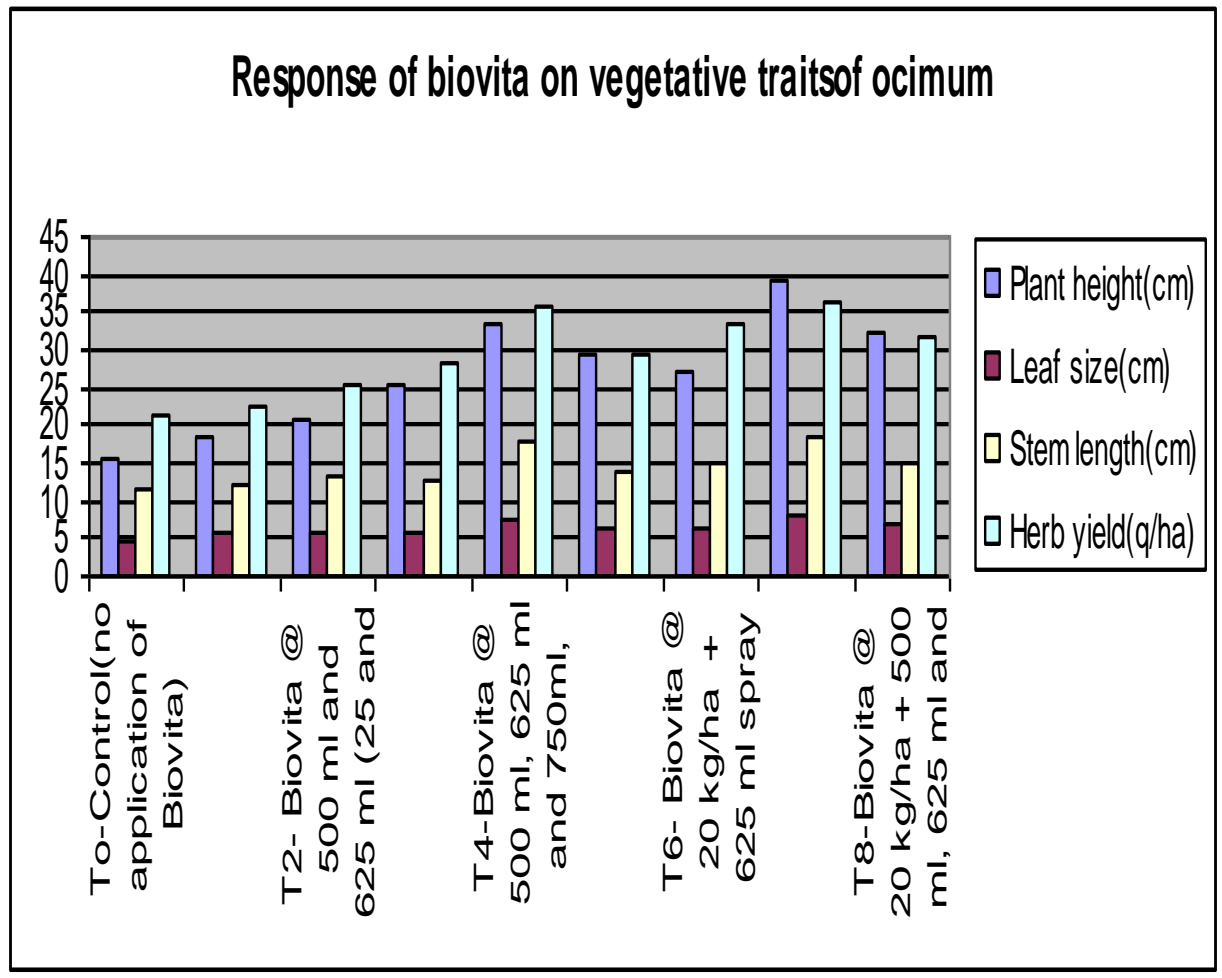

It also contributes to a greater extent in microbial activities in the soil, thus increasing nutrients availability, yield and quality traits.

From the present investigation it can be concluded that the highest plant height, leaf size, stem length, maximum herb yield, highest oil content, highest linalool (\%), methyl chavicol (\%) and highest gross return was found in biovita @ $20 \mathrm{~kg} / \mathrm{ha}+500 \mathrm{ml}+$ $625 \mathrm{ml} / \mathrm{ha}$ and minimum values were associated with control.

\section{References}

Alkaff, H.A., and Hassan AA 2003. Effect of Biofertilizers and organic fertilizer on the growth and yield of okra plants. Univ. Aden. Natural and Applied Sci., 7(1): 25-35.

Panse, V.G., and Sukhatme PV 1989. Statistical methods for Agricultural workers. ICAR. New Delhi.

Thakar, N.A., Patel HR and Patel CC 1987. Azolla in management of root-knot disease in okra. Indian J. Nematology, 17(1): 136-137.

\section{How to cite this article:}

Swati Barche and Kamal S. Kirad. 2018. Effect of Botanical Fertilizer on Herb Yield and Quality of Basil (Ocimum canum L.). Int.J.Curr.Microbiol.App.Sci. 7(01): 3167-3170. doi: https://doi.org/10.20546/ijcmas.2018.701.377 